\title{
Essential oil and monensin affect ruminal fermentation and the protozoal population in continuous culture
}

\author{
D. Ye, ${ }^{* 1}$ S. K. R. Karnati, ${ }^{* 2}$ B. Wagner, ${ }^{*}$ J. L. Firkins, ${ }^{*}$ M. L. Eastridge,${ }^{* 3}$ and J. M. Aldrich $\dagger^{4}$ \\ ${ }^{*}$ Department of Animal Sciences, The Ohio State University, Columbus 43210 \\ †Provimi-North America, Lewisburg, OH 45338
}

\begin{abstract}
The interaction of monensin and essential oil was hypothesized to suppress protozoa and methane production while maintaining normal rumen function. The objective of this study was to determine the effects of feeding monensin (MON) and CinnaGar (CIN, a commercial blend of cinnamaldehyde and garlic oil; Provimi North America, Brookville, $\mathrm{OH}$ ) on ruminal fermentation characteristics. Continuous culture fermentors (n $=4$ ) were maintained in 4 experimental periods in a 4 $\times 4$ Latin square design. Four dietary treatments were arranged in a $2 \times 2$ factorial: (1) control diet, $37 \mathrm{~g} / \mathrm{d}$ of dry matter $(40 \mathrm{~g} / \mathrm{d}$ at $\sim 92.5 \%$ dry matter) of a $50: 50$ forage:concentrate diet containing no additive; (2) MON at $11 \mathrm{~g} / 909 \mathrm{~kg}$ of dry matter; (3) CIN at $0.0043 \%$ of dry matter; and (4) a combination of MON and CIN at the levels in (2) and (3). Treatment had no effects on protozoal populations, concentration of $\mathrm{NH}_{3} \mathrm{~N}$, total $\mathrm{N}$ flow of effluent, production of total volatile fatty acids, or flows of conjugated linoleic acid and total C18 fatty acids. The MON decreased acetate:propionate ratio and biohydrogenation of both total C18 and 18:1 cis-9 but increased protozoal generation time, concentration of peptide, and flow of 18:1 trans-11. The MON tended to decrease protozoal counts in effluent and flow of 18:0 but tended to increase propionate production. The CIN decreased true organic matter digestibility and protozoal $\mathrm{N}$ flow of effluent but increased nonammonia, nonmicrobial $\mathrm{N}$ flow. The CIN tended to decrease protozoal counts, microbial $\mathrm{N}$ flow, and neutral detergent fiber digestibility but tended to increase biohydrogenation of total C18, 18:2, and 18:3. The CIN tended to increase isovalerate production. The MON
\end{abstract}

Received August 8, 2017.

Accepted February 1, 2018.

${ }^{1}$ Current address: Cumberland Valley Analytical Services, Waynesboro, PA 17268.

${ }^{2}$ Current address: The Procter \& Gamble Company, Mason, OH 45040.

${ }^{3}$ Corresponding author: eastridge.1@osu.edu

${ }^{4}$ Current address: CSA Animal Nutrition, Dayton, OH 45414. and CIN tended to interact for increased methane production and bacterial $\mathrm{N}$ flow. A second experiment was conducted to determine the effects of MON and CIN on protozoal nitrogen and cell volume in vitro. Four treatments included (1) control (feed only), (2) feed + $0.0043 \%$ dry matter CIN, (3) feed $+2.82 \mu M \mathrm{MON}$, and (4) feed + CIN + MON at the same levels as in (2) and (3). With no interactions, MON addition decreased percentage of protozoa that were motile and tended to decrease cell volume at $6 \mathrm{~h}$. The CIN did not affect cell count or other indicators of motility or volume at either 3 or $6 \mathrm{~h}$. Under the conditions of our study, we did not detect an additive response for MON and CIN to decrease protozoal counts or methane production. A 3 -dimensional method is suggested to better estimate protozoal cell volume.

Key words: essential oil, monensin, protozoa, continuous culture

\section{INTRODUCTION}

Increasing public concern over climate change and increasing emphasis on rumen-derived methanogenesis have directed considerable research efforts to investigating suppression of ruminal protozoa because of their close association with methanogens (Newbold et al., 2015). By decreasing methanogenesis in the rumen, reducing equivalents may be directed to propionate (the major gluconeogenic precursor in ruminants) rather than being eructated. This strategy of inhibiting protozoa to reduce methanogenesis is complicated because results have not been found to be long lasting and reduced protozoal concentrations are not always correlated with reduced methane production (Williams et al., 2009).

The use of essential oil (EO), including cinnamaldehyde, as an alternative to antibiotics in animals is gaining wide attention because of its antimicrobial property, likely a result of microbial cell membrane disruption (Gill and Holley, 2004), but the activity is nonspecific against bacteria, protozoa, and fungi (Cobellis et al., 2016). Many EO also have suppressed methanogenesis (Cobellis et al., 2016). Essential oils have been 
suggested as a potential tool for manipulation of the bacterial populations involved in ruminal biohydrogenation of fatty acids (FA; Calsamiglia et al., 2007). Cinnamaldehyde decreased apparent biohydrogenation of 18:2n- 6 and $18: 3 n-3$ in a continuous culture fermentor system and shifted the biohydrogenation from the trans-11 pathway to the accumulation of 18:1 trans-10 and trans-10,cis-12 CLA (Lourenço et al., 2008). This trans-10 shift has been documented to cause milk fat depression in vivo (Jenkins et al., 2008). However, supplementation of TMR for lactating dairy cows with cinnamaldehyde $(1 \mathrm{~g} / \mathrm{d})$ did not modify the FA profile of milk fat (Benchaar and Chouinard, 2009).

Monensin (MON) has decreased the rate of ruminal biohydrogenation of UFA in vitro (Fellner et al., 1997) and increased the concentration of CLA in milk fat (AlZahal et al., 2008). Protozoa adapt to MON by changing their membrane structure (Karnati et al., 2009; Sylvester et al., 2009). However, it is unknown if EO along with MON would suppress protozoa long term. Moreover, direct suppression of protozoa (with a specific inhibitor) could limit fermentation rate and increase the generation time of protozoa, making them less competitive and thus lowering their biomass in the rumen (Karnati et al., 2009).

The suppression of ruminal microbes, especially protozoa, by EO and MON is not fully understood, and limited data are available on the effects of a combination of MON and EO. The MON inhibits hydrogen-producing bacteria (Chen and Wolin, 1979) and causes depletion of energy reserves (Tedeschi et al., 2003). Membrane leaks could occur with decay of proton motive force when the protein:lipid of the membrane increases in artificial liposomes (Russell and Strobel, 1989). However, more current information suggests that sensitivity to MON depends on specific cell wall susceptibility, not previous associations with gram-positive and gram-negative staining (Scharen et al., 2017). In that study, protozoal counts were not associated with MON or EO supplementation, apparently as a result of adaptation, and a combination of MON and EO was not studied. Nutrient stress could cause increased autophagy or decreased protozoal cells in division state (Berger, 2001). Thus, cellular adaptations associated with decreasing volume and cellular protein concentrations are assumed to be a stress response to introduction of MON and EO.

We hypothesized that an interaction of MON with CinnaGar (a blend of cinnamaldehyde and garlic oil) would suppress protozoa and their associated methanogens, but this suppression must be characterized within the context of compensatory increases in the bacterial activity to outcompete protozoa during their adjustment to these additives. The objective of this study was to determine the effects of feeding MON and CinnaGar in diets on ruminal fermentation characteristics, nutrient digestibility, and microbial efficiency in continuous culture and protozoal counts and their cell volume after adaptation to these additives.

\section{MATERIALS AND METHODS}

\section{Design of Experiment 1}

A modified dual-flow continuous culture system was used in the study. Four continuous culture fermentors in a $4 \times 4$ Latin square design were modified to retain protozoa and maintained in 4 periods of $10 \mathrm{~d}$ each $(7 \mathrm{~d}$ of adaptation). The fermentors were fed once daily 37 $\mathrm{g} / \mathrm{d}$ of DM $(40 \mathrm{~g} / \mathrm{d}$ at $\sim 92.5 \% \mathrm{DM})$ of a $50: 50$ forage: concentrate diet (38\% NDF, $16 \% \mathrm{CP}$ ) containing either no additive, MON (Elanco Animal Health, Greenfield, IN) as Rumensin at $11 \mathrm{~g} / 909 \mathrm{~kg}$ of DM in the pelleted concentrate, CinnaGar (CIN) provided by Provimi North America (Brookville, OH) at $0.0043 \%$ of feed mixture DM, or MON (11 g/909 kg of DM) plus CIN (0.0043\% DM basis; Tables 1 and 2). The CIN was provided just before initiation of our study and was kept sealed and refrigerated to prevent volatilization of active product. The dosage of MON is based on the company label, and the dose of CIN is comparable to $1 \mathrm{~g} / \mathrm{d}$ of cinnamaldehyde to dairy cattle (assuming 23 $\mathrm{kg} / \mathrm{d}$ of DMI) as justified by Benchaar and Chouinard (2009).

The dual-flow continuous culture system was based on the system initially described by Hoover et al. (1976). For each period, ruminal contents were taken $2 \mathrm{~h}$ postfeeding from 2 cannulated Holstein cows that were maintained on a diet (approximately 50\% forage with corn silage as the primary forage) without EO or MON at The Ohio State University's Waterman Dairy Center. The contents were pooled and squeezed through 2 layers of cheesecloth into a container maintained at $39^{\circ} \mathrm{C}$. After being transported to the laboratory, the rumen fluid was re-strained through 2 layers of cheesecloth, and $500 \mathrm{~mL}$ was inoculated into each fermentor, then buffer was added while mixing to fill up to the overflow level. As described in Karnati et al. (2009), a multi-stage filter system was used on the pumps to retain protozoa. The volumes of the 4 fermentors ranged from 1.63 to $1.81 \mathrm{~L}$. The $\mathrm{pH}$ in the fermentors was monitored and adjusted between 6.4 and 6.8 during the feeding cycle of the adaptation phase and was unchanged during the collection phase. Temperature was maintained at $39^{\circ} \mathrm{C}$, and agitation was set at $50 \mathrm{rpm}$. Flow rates were determined once a day during the adaptation period by weighing solid (overflow) and liquid (filtrate plus overflow) outflows from each fermentor 
Table 1. Ingredient and nutrient composition of diets without (-) or with (+) monensin and CinnaGar in experiment $1^{1}$

\begin{tabular}{|c|c|c|c|c|}
\hline \multirow[b]{2}{*}{ Item } & \multicolumn{4}{|c|}{ Monensin/CinnaGar ${ }^{2}$} \\
\hline & $-/-$ & $-/+$ & $+/-$ & $+/+$ \\
\hline \multicolumn{5}{|l|}{ Ingredient ( $\%$ of $\mathrm{DM})$} \\
\hline Alfalfa meal & 50.0 & 50.0 & 50.0 & 50.0 \\
\hline Soybean hulls & 20.4 & 20.4 & 20.4 & 20.4 \\
\hline Corn, ground & 18.1 & 18.1 & 18.1 & 18.1 \\
\hline Distillers grains with solubles & 5.00 & 5.00 & 5.00 & 5.00 \\
\hline Soybean meal, $48 \%$ CP & 4.50 & 4.50 & 4.50 & 4.50 \\
\hline Corn oil & 1.00 & 1.00 & 1.00 & 1.00 \\
\hline Trace mineral salt & 0.50 & 0.50 & 0.50 & 0.50 \\
\hline Dicalcium phosphate & 0.43 & 0.43 & 0.43 & 0.43 \\
\hline Magnesium oxide & 0.11 & 0.11 & 0.11 & 0.11 \\
\hline Rumensin & - & - & 0.009 & 0.009 \\
\hline CinnaGar & - & 0.0043 & - & 0.0043 \\
\hline \multicolumn{5}{|l|}{ Nutrient (\% of DM) } \\
\hline $\mathrm{DM}$ & 93.1 & 93.3 & 93.2 & 92.7 \\
\hline $\mathrm{OM}$ & 91.5 & 91.5 & 91.6 & 91.5 \\
\hline $\mathrm{NDF}$ & 38.8 & 39.3 & 38.4 & 37.7 \\
\hline $\mathrm{CP}$ & 17.0 & 16.7 & 16.6 & 16.8 \\
\hline
\end{tabular}

${ }^{1}$ Diets were fed at $37 \mathrm{~g} / \mathrm{d}$ of DM.

${ }^{2}$ Rumensin was provided by Elanco Animal Health (Greenfield, IN); CinnaGar was provided by Provimi North America Inc. (Brookville, OH).

and adjusted as necessary to maintain 5.0 and $7.0 \% / \mathrm{h}$ solids and liquid dilution rates, respectively.

\section{Fermentor Sample Collection and Analyses (Experiment 1)}

On d 5 of each period, $10 \%$ enriched $\left({ }^{15} \mathrm{NH}_{4}\right)_{2} \mathrm{SO}_{4}$ was added at $25 \mathrm{mg} / \mathrm{L}$ to the buffer for a desired enrichment of $0.2 \%$ atom excess for use as a bacterial marker. At the same time, $1 \mathrm{~mL}$ of the $\left({ }^{15} \mathrm{NH}_{4}\right)_{2} \mathrm{SO}_{4}$ solution was primed into each fermentor. A sample of effluent was taken before the priming for background ${ }^{15} \mathrm{~N}$. On d 6 , formalin ( $1 \% \mathrm{wt} / \mathrm{vol}$ final dose) was added at $2 \%$ of the volume of the solid and liquid overflows to preserve the effluent for protozoa counts. It was divided into 3 aliquots at 0,6 , and $12 \mathrm{~h}$. Also, $10 \mathrm{~mL}$ of fermentor samples was taken at $0,4,8$, and $12 \mathrm{~h}$ for protozoa counts (Dehority, 1993). On d 7, another $10 \mathrm{~mL}$ of fixed effluent was collected for protozoa counts, which were used to calculate the generation time of protozoa and protozoal populations. The results were grouped into Entodinium spp., family Isotrichidae including Dasyt-

Table 2. Fatty acid (FA) composition of the dietary treatments without $(-)$ or with $(+)$ monensin and CinnaGar in experiment $1^{1}$

\begin{tabular}{lcccc}
\hline & \multicolumn{4}{c}{ Monensin/CinnaGar ${ }^{2}$} \\
\cline { 2 - 5 } Item & $-/-$ & $-/+$ & $+/-$ & $+/+$ \\
\hline Total FA (\% of DM) & 2.03 & 2.07 & 2.07 & 2.05 \\
Individual FA (g/100 g of FA) & 17.3 & 17.4 & 17.5 & 17.4 \\
16:0 & 3.12 & 3.11 & 3.11 & 3.11 \\
$18: 0$ & 16.0 & 16.4 & 16.3 & 16.4 \\
$18: 1$ cis-9 & 0.78 & 0.80 & 0.79 & 0.79 \\
$18: 1$ cis-11 & 0.40 & 0.44 & 0.48 & 0.49 \\
$18: 1$ trans & 37.9 & 38.2 & 38.8 & 37.8 \\
18:2n-6 & 1.16 & 1.12 & 1.11 & 1.15 \\
CLA & 0.77 & 0.76 & 0.76 & 0.77 \\
18:3n-6 & 15.4 & 15.1 & 15.0 & 15.4 \\
18:3n-3 & & & \\
\hline
\end{tabular}

${ }^{1}$ Diets contained monensin at $11 \mathrm{~g} / 909 \mathrm{~kg}$ or CinnaGar at $0.0043 \%$ on a DM basis.

${ }^{2}$ Rumensin was provided by Elanco Animal Health (Greenfield, IN); CinnaGar was provided by Provimi North America Inc. (Brookville, OH).

${ }^{3}$ Consisted of 18:1 trans-10, trans-12, and trans-13.

${ }^{4}$ Geometrical and positional isomers of conjugated linoleic acid. 


\title{
Composited effluent
}

$\downarrow$

\section{Collected to container with a final concentration of $1 \%$ of formalin}

\author{
Centrifuge at $500 \times g$ at $4^{\circ} \mathrm{C}$ for $10 \mathrm{~min}$ \\ $\downarrow$ \\ Collect the pellet
}

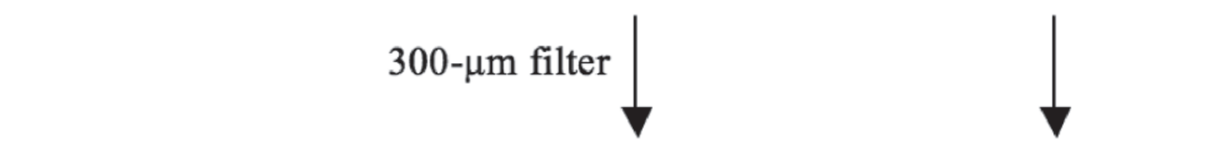

Take samples for $\mathrm{N}$ and cell number

Filtrate 1

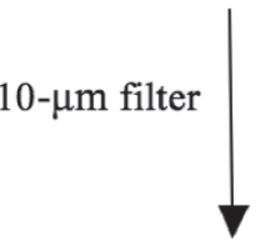

Take samples for $\mathrm{N}$ and cell number

\section{Retentate 1}

Take samples for $\mathrm{N}$ and

Filtrate 2 cell number

Boil in water bath for $5 \mathrm{~min}$; sonicate for $2 \mathrm{~min} ; 10-\mu \mathrm{m}$ filter

Retentate 2 Take samples for $\mathrm{N}$ and cell number

Figure 1. Procedure of boiling and sonication on protozoa. Lost protozoal $\mathrm{N}=\mathrm{N}$ from retentate $1-\mathrm{N}$ from retentate 2 . Protozoal cells

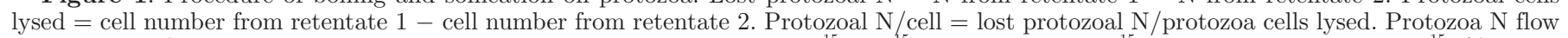
$=$ protozoa $\mathrm{N} /$ cell $\times$ protozoa cells per day in effluent flow. Lost protozoa ${ }^{15} \mathrm{~N}={ }^{15} \mathrm{~N}$ in retentate $1-{ }^{15} \mathrm{~N}$ in retentate 2 . Protozoa ${ }^{15} \mathrm{~N} \%=$ lost protozoa ${ }^{15} \mathrm{~N} /$ lost protozoa $\mathrm{N}$. Protozoa ${ }^{15} \mathrm{~N}$ flow $=$ protozoa ${ }^{15} \mathrm{~N} \% \times$ protozoa $\mathrm{N}$ flow.

richa and Isotricha, and subfamily Diplodiniinae. On d 8,9 , and 10 of each period, a sample of $20 \%$ of total daily effluent was collected overnight on ice, composited by fermentor within period, and lyophilized. The lyophilized subsample was analyzed for DM, OM, and $\mathrm{N}$ using the Kjeldahl method (AOAC International, 1990), NDF in the presence of heat-stable amylase and sodium sulfite but without ash correction (Van Soest et al., 1991), and ammonia (Noftsger et al., 2003). Digestibility values were determined from known feeding amounts and analysis of feeds, measurement of effluent volume, and respective analysis of the effluent samples for components of interest.

Aliquots of effluent samples and background samples (taken before ${ }^{15} \mathrm{~N}$ infusion) were adjusted to $\mathrm{pH}>10$ with $25 \% \mathrm{NaOH}$ to volatilize ammonia from the sample (Noftsger et al., 2003) and dried at $90^{\circ} \mathrm{C}$ overnight before ${ }^{15} \mathrm{~N}$ analysis of the nonammonia $\mathrm{N}$ (NAN) using by isotope-ratio MS at Pennsylvania State University (Hristov et al., 2001). Similar procedures were used for bacterial samples and protozoal retentates from Figure
1. The ${ }^{15} \mathrm{~N}$ of ammonia was assessed by the diffusion protocol (Hristov et al., 2001). All samples were corrected for natural abundance from pre-dosing samples. An aliquot of the effluent sample was strained through 4 layers of cheesecloth. The filtrate was acidified using $3 \mathrm{~mL}$ of $6 \mathrm{~N} \mathrm{HCl}$ per $50 \mathrm{~mL}$ of filtrate to stop fermentation before analysis for VFA (Firkins et al., 1990). The gas collection and analysis were as described in Karnati et al. (2009). The long-chain FA in the freeze-dried effluent samples were methylated, analyzed, and biohydrogenation of FA calculated as previously described (Mathew et al., 2011).

An aliquot of the effluent sample, ranging from 210 to $250 \mathrm{~mL}$, was fixed in formalin for the protozoal $\mathrm{N}$ :cell ratio, which was determined using a revised procedure based on the method in Williams and Coleman (1992; Figure 1). Sample N (Kjeldahl method) and cell counts (Dehority, 2010) were determined before and after boiling in a water bath and sonication with an ultrasonic cleaning bath of average output $80 \mathrm{kHz}$. The protozoal $\mathrm{N}$ :cell was calculated by dividing the loss of $\mathrm{N}$ into 
the loss of protozoal cells after boiling and sonication versus the original sample.

The protozoal N:cell was multiplied by total outflow of protozoa cells to determine protozoal $\mathrm{N}$ flow. Because of the large amount of contaminating feed $\mathrm{N}$ that was recovered in protozoal fractions, 2 approaches were compared to calculate protozoal ${ }^{15} \mathrm{~N}$ enrichment subtraction from total ${ }^{15} \mathrm{~N}$ in NAN to quantify bacterial $\mathrm{N}$ flow without bias. For one method, the protozoal ${ }^{15} \mathrm{~N}$ enrichment (atom fraction above background) was calculated as the quotient of the ${ }^{15} \mathrm{~N}$ (corrected for background) and total $\mathrm{N}$ that was not recovered from control (not boiled or sonicated, NBS) after boiling and sonication (Figure 1). This derived enrichment of protozoa ${ }^{15} \mathrm{~N}$ was multiplied by protozoal $\mathrm{N}$ flow (derived from $\mathrm{N} /$ cell and protozoal cell flow) to calculate protozoal ${ }^{15} \mathrm{~N}$ flow. For the second method, only the protozoal ${ }^{15} \mathrm{~N}$ from NBS retentate was used to backcalculate protozoa ${ }^{15} \mathrm{~N}$ amount in the 3 -d composited effluent sample, which was converted to protozoal ${ }^{15} \mathrm{~N}$ flow by multiplying effluent outflow per day. Then the ${ }^{15} \mathrm{~N}$ flow in NAN was corrected for protozoal ${ }^{15} \mathrm{~N}$ using both of these approaches, and the difference was divided by ${ }^{15} \mathrm{~N}$ enrichment in harvested bacterial cells to compute bacterial $\mathrm{N}$ flow.

We used a crossed stage micrometer as a horizontal and vertical scale (type NE17 with a $21 \mathrm{~mm}$ diameter, Electron Microscopy Sciences, Hatfield, PA) on the microscope eyepiece to measure the length and width of about 100 random Entodinium mixed species from each treatment of the NBS retentates to estimate the protozoal cell volume to determine the effect of treatment on the Entodinium sizes. We compared 2 different calculations for protozoal cell volume: (1) volume = length(length $/ 4)^{2} \pi$ (Teather et al., 1984); and (2) volume $=\operatorname{length}(\text { width } / 2)^{2} \pi$ (Dehority, 2010).

\section{Experiment 2: Batch Culture and Sample Analyses}

A second experiment was conducted in vitro as a follow-up from experiment 1 to more directly assess the effects of MON and CIN on protozoal $\mathrm{N}$ and cell volume using some new techniques (Wenner et al., 2018) and accounting for potential artifact from CIN interacting with feed proteins in the protozoal fraction. Rumen fluid was collected as described previously except that it was from 2 cannulated lactating Jersey cows. Following transport back to the laboratory, the sample was diluted in an equal part of Simplex Buffer (Hackmann et al., 2013). This buffer contained 11.430 $\mathrm{g}$ of $\mathrm{K}_{2} \mathrm{HPO}_{4}, 9.0 \mathrm{~g}$ of $\mathrm{KH}_{2} \mathrm{PO}_{4}, 1.170 \mathrm{~g}$ of $\mathrm{NaCl}, 0.162$ $\mathrm{g}$ of $\mathrm{MgSO}_{4} \cdot 7 \mathrm{H}_{2} \mathrm{O}, 13.5 \mathrm{~g}$ of $\mathrm{NaHCO}_{3}, 19.8 \mathrm{~mL}$ of $2 \%$ (wt/vol) L-cysteine $\mathrm{HCl}, 18$ drops of $0.1 \%$ Rezazurin, and $2.1 \mathrm{~L}$ of distilled $\mathrm{H}_{2} \mathrm{O}$. After flocculation for 30 min followed by aspiration of floating feed particles, $30 \mathrm{~mL}$ of inoculum were distributed anaerobically into tubes containing pre-weighed dietary treatments. The 4 treatments included (1) control (feed only), (2) feed $+0.0043 \%$ CIN (DM basis), (3) feed $+2.82 \mu M$ MON, and (4) feed + CIN + MON at the same levels as in (2) and (3). Treatment concentration was consistent with manufacturers' feeding recommendations and was added as a percent of the diet, consistent with the previous experiment. The feed mixture consisted of $70 \%$ cellulose (Sigmacell 20, catalog \#S-3504, Sigma-Aldrich Co. LLC, St. Louis, MO), 25\% potato starch (catalog \#9005-25-8, Sigma-Aldrich Co. LLC), and 5\% glucose (catalog \#50-99-7, ACROS Organics, Thermo Fisher Scientific, Waltham, MA); $0.5 \mathrm{~g}$ was dosed per incubation. This specific feed mixture was chosen due to its lack of $\mathrm{N}$, ensuring that all $\mathrm{N}$ measured during postexperiment analyses was from inoculum or resultant microbial growth.

The experiment consisted of 4 treatments and 3 time points at 0,3 , and $6 \mathrm{~h}$, each done in duplicate, for 4 replicate incubations. Immediately after termination of incubation, $40 \mu \mathrm{L}$ was sampled for video documentation (final 2 replicates only) and the remaining volume was fixed in $1 \%$ formalin for future protozoal filtering based on filtration as described by Sylvester et al. (2004). After repeated washing in $0.9 \%$ saline, the filtrate was formalinized ( $1 \%$ final concentration of $\mathrm{HCHO}$ ) for subsequent analysis of cell counts (Dehority, 2010) and $\mathrm{N}$ (Kjeldahl method), allowing determination of $\mathrm{N}$ per cell.

A $40-\mu \mathrm{L}$ representative sample of each tube was wet mounted on a stage micrometer for video recording. Videos ( $\mathrm{n}=9$ per tube, $10 \mathrm{~s}$ each) for each tube were used to evaluate treatment effect on the percentage of protozoa that were motile or viable (i.e., if cilia were moving but the cell was not, it was deemed motile). All protozoa were counted (average $\mathrm{n}=384$ per treatment at $6 \mathrm{~h}$ ). Protozoal volume while swimming (to capture both the depth and width) was also estimated using the ellipsoid formula proposed in Wenner et al. (2018) using ImageJ (Schneider et al., 2012).

\section{Statistical Analyses}

Data for experiment 1 were analyzed using the MIXED procedure (SAS, version 9.4, SAS Institute Inc., Cary, NC) with period and treatment as fixed effects and fermentor as the random effect. In experiment 2 , the count data (cells/mL) were normalized by $\log _{10}$ transformation before statistical analysis. Volume data by the ellipsoid method (Wenner et al., 2018) were weighted using the inverse of standard deviation to account for variability among measurements. Data 
for $\log _{10}$ cells and $\mathrm{N}$ (ng/cell) were analyzed using the MIXED procedure (SAS Institute Inc.), with period, treatment, and hour as fixed effects and replicate as a random effect. Data for motility also were analyzed using MIXED procedure (SAS Institute Inc.) in a similar manner except time zero was used as a covariate. The volume data included $0 \mathrm{~h}$ as a covariate for both 3 and $6 \mathrm{~h}$ postinoculation samples. In both experiments, the main effects of MON and CIN and their interaction were compared using the contrasts of MON, CIN, and MON $\times$ CIN $(3 \mathrm{df})$ as reported in the respective tables. Significance was declared at $P \leq 0.05$, and trends were noted at $0.05<P \leq 0.15$.

\section{RESULTS AND DISCUSSION}

\section{Protozoa Counts, Generation Time, and Volume}

Neither MON nor an interaction of MON and CIN affected total counts of protozoa (Table 3), contrary to our hypothesis. Various species of entodiniomorphids were inhibited by MON, apparently through disrupted digestive capacity (Sylvester et al., 2009). The CIN tended to decrease total protozoal counts $(P=0.07)$ and therefore effluent flow of cells per day $(P=0.09)$. In contrast, the percentage of counts for Entodinium in fermentors (comprising $>90 \%$ of cells) tended $(P=$ 0.12 ) to be greater for CIN. Previously, Benchaar et al. (2008) reported that supplementing cinnamaldehyde at $1,000 \mathrm{mg} / \mathrm{d}$ to Holstein cows had no effect on the total counts of protozoa, as well as numbers of Dasytricha spp., Diplodinium spp., Entodinium spp., and Polyplastron spp., and tended to increase the number of Isotricha spp. Cardozo et al. (2006) reported that cinnamaldehyde $(180 \mathrm{mg} / \mathrm{d})$ plus eugenol $(90 \mathrm{mg} / \mathrm{d})$ fed to beef cattle tended to decrease the counts of Entodinium spp. and increased the counts of Isotricha spp. $3 \mathrm{~h}$ after feeding. Other EO were concluded to decrease the protozoa counts only at high doses, and results varied among different types of EO (Hart et al., 2008). Although the type of EO and the experimental conditions (e.g., continuous culture or in vivo) can affect the results of EO supplementation, microbial populations exhibit a remarkable capacity to adapt to or degrade the $\mathrm{EO}$, particularly in low dosage rates in vitro (Benchaar, 2016).

A trend $(P=0.13)$ was observed for MON to decrease the effluent flow of cells per day (Table 3). The MON increased the generation time, probably because of an increase in microbial energy requirements for maintenance at a low growth rate (Bergen and Bates, 1984). The MON was previously noted to increase generation time during adaptation, but the generation time typically decreased to near the control diet by about $7 \mathrm{~d}$, apparently as a result of protozoa altering their membrane structure to regain the ability to lower $\mathrm{pH}$ (Sylvester et al., 2009). This suggests that the 7-d adaptation to MON either was not quite complete by

Table 3. Protozoal counts, generation time, populations, and protozoa cell volume in continuous cultures fed diets without $(-)$ or with $(+)$ Monensin and CinnaGar in experiment $1^{1}$

\begin{tabular}{|c|c|c|c|c|c|c|c|c|}
\hline \multirow[b]{2}{*}{ Item } & \multicolumn{4}{|c|}{ Monensin/CinnaGar² } & \multirow[b]{2}{*}{ SEM } & \multicolumn{3}{|c|}{$P$-value ${ }^{3}$} \\
\hline & $-/-$ & $-/+$ & $+/-$ & $+/+$ & & CIN & $\mathrm{MON}$ & $\mathrm{CIN} \times \mathrm{MON}$ \\
\hline Total count $\left(10^{3} \times \mathrm{mL}^{-1}\right)$ & 20.5 & 13.6 & 18.1 & 16.8 & 1.9 & 0.07 & NS & NS \\
\hline Generation time $^{4}(\mathrm{~h})$ & 22.0 & 22.3 & 27.0 & 28.2 & 1.2 & NS & $<0.01$ & NS \\
\hline \multicolumn{9}{|l|}{ Populations in fermentor ( $\%$ of total) } \\
\hline Entodinium & 90.8 & 93.7 & 90.2 & 92.1 & 4.0 & 0.12 & NS & NS \\
\hline \multicolumn{9}{|l|}{ Populations in effluent ( $\%$ of total) } \\
\hline Entodinium & 92.2 & 94.5 & 93.3 & 93.8 & 1.8 & NS & NS & NS \\
\hline Isotrichida $^{5}$ & 6.65 & 3.40 & 2.74 & 3.33 & 1.70 & NS & NS & NS \\
\hline Diplodiniinae $^{6}$ & 0.60 & 2.08 & 2.17 & 1.41 & 0.95 & NS & NS & NS \\
\hline Mean length:width & 1.58 & 1.50 & 1.65 & 1.52 & 0.04 & 0.08 & NS & NS \\
\hline Protozoa cell volume ${ }^{7}\left(\times 10^{4} \mu \mathrm{m}^{3}\right)$ & 2.75 & 2.65 & 2.76 & 3.05 & 0.28 & NS & NS & NS \\
\hline Protozoa cell volume $^{8}\left(\times 10^{4} \mu \mathrm{m}^{3}\right)$ & 4.69 & 5.11 & 4.09 & 5.53 & 0.41 & 0.09 & NS & NS \\
\hline
\end{tabular}

${ }^{1}$ Diets contained monensin at $11 \mathrm{~g} / 909 \mathrm{~kg}$ or CinnaGar at $0.0043 \%$ on a DM basis.

${ }^{2}$ Rumensin was provided by Elanco Animal Health (Greenfield, IN); CinnaGar was provided by Provimi North America Inc. (Brookville, OH).

${ }^{3}$ Main effects or interaction of monensin (MON) and CinnaGar (CIN). NS: $P>0.15$.

${ }^{4}$ Generation time $=$ fermentor pool size (counts $\times$ volume) in fermentor/effluent flow of protozoa cells per hour (Sylvester et al., 2004).

${ }^{5}$ Family, including the genera Dasytricha and Isotricha.

${ }^{6}$ Subfamily, including the genera Diplodinium, Eudiplodinium, Enoploplastron, Metadinium, Ostracodinium, and Polyplastron.

${ }^{7}$ Length $\times \pi \times\left[(\text { length } / 4)^{2}\right]$ (Teather et al., 1984).

${ }^{8}$ Length $\times \pi \times\left[(\text { width } / 2)^{2}\right]$ (Dehority, 2010). 
our sampling period or was energetically costly such that generation time was increased by MON. Another possible explanation would be the way MON was administered. Karnati et al. (2009) observed MON to have no effect on generation time when MON was infused as liquid. However, in the current study, MON was mixed and processed with other feed components into pellets, by which MON might be more readily available to interact with protozoa consuming plant particles.

The length:width tended to decrease $(P=0.08)$, whereas protozoal cell volume as estimated by the cylinder approach tended to increase $(P=0.09)$ for CIN compared to without CIN (Table 3). This relationship was one justification for improving how protozoal volume can be estimated, leading to the development of an ellipsoid method to account for large differences in depth:width among protozoa (Wenner et al., 2018). This approach was developed after experiment 1 but was used in experiment 2 because of its potential to improve estimation of protozoal volume given the differing shapes of various genera. The MON severely depressed the motility of protozoa in experiment 2 (Table 4). Although counts were not affected in experiment 2, the $\mathrm{N} /$ cell was higher at $3 \mathrm{~h}$, but volume tended to be lower $(P=0.10)$ for MON by about $0.1 \log$ unit $(21.5 \%$ on an actual basis) at $6 \mathrm{~h}$. Wenner et al. (2018) noted that MON slowed swimming speed at 3 and $6 \mathrm{~h}$. Diaz et al. (2014) concluded that the inhibitor wortmannin disrupted phagocytosis and digestive vacuole maturation, decreasing random swimming resulting from decreased energy status, but this inhibitor increased chemotactic swimming when presented with a glucose gradient. In the current study, abrupt MON addition also probably lowered energy status through decreased digestive capacity, perhaps blocking normal digestion and excretion (digestive vacuole trafficking) at the early introduction. This may potentially explain the higher N:cell at $3 \mathrm{~h}$ (Table 4), but at $6 \mathrm{~h}$, this inhibition might have de- creased consumption of substrate (e.g., starch granules) and decreased volume.

\section{Digestibility of Nutrients}

There was no main effect of adding CIN on apparent OM digestibility. However, CIN decreased true OM digestibility (corrected for microbial OM in effluent) by $6.62 \%$ and tended $(P=0.11)$ to decrease NDF digestibility (Table 5). Digestibilities of NDF and OM were not affected by MON. Protozoa have lower fibrolytic enzyme activity compared with that in fibrolytic bacteria but probably indirectly increase the NDF digestibility by quenching oxygen or degrade starch more slowly and help avoid a decrease of ruminal $\mathrm{pH}$, optimizing the environment for fibrolytic bacteria (Firkins and $\mathrm{Yu}$, 2006). Thus, the tendency of reduced total protozoal counts could be part of the cause of decreased true OM digestibility with CIN. The result in our study was inconsistent with Busquet et al. (2005), who noted that cinnamaldehyde and garlic oil additions at both low and high levels did not affect the true OM and NDF digestibilities in continuous cultures fed a 50:50 alfalfa hay:concentrate mixture. In another trial of that report, MON added at $12.5 \mathrm{mg} / \mathrm{L}$ decreased NDF digestibility in vitro, whereas the MON in our study added at $11 \mathrm{~g} / 909 \mathrm{~kg}$ of DM, approximately $0.34 \mu \mathrm{M}$, had no effect on digestibility, which is consistent with the previous study in our laboratory (Karnati et al., 2009) when MON was dosed in the liquid phase at $2.5 \mu \mathrm{M}$ in the continuous culture with a 70:30 forage:concentrate mixture.

\section{N Flows and $\mathrm{NH}_{3} \mathrm{~N}$ Concentration}

There were no significant main effects or interactions of treatments for $\mathrm{NH}_{3} \mathrm{~N}$ concentrations, effluent flows of total $\mathrm{N}$ and NAN, or N efficiency (Table 5). The

Table 4. Protozoal counts, protozoa nitrogen, live:dead ratio, and volume in batch culture administered treatments without $(-)$ or with $(+)$ monensin and CinnaGar in experiment $2^{1}$

\begin{tabular}{|c|c|c|c|c|c|c|c|c|}
\hline Item & \multicolumn{4}{|c|}{ Monensin/CinnaGar ${ }^{2}$} & SEM & \multicolumn{3}{|c|}{$P$-value ${ }^{3}$} \\
\hline Total counts $\left(10^{3} \times \mathrm{mL}^{-1}\right)$ & 4.94 & 5.13 & 5.26 & 5.05 & 0.83 & NS & NS & NS \\
\hline Protozoal N, 6 h (ng/cell) & 1.09 & 1.14 & 1.19 & 1.12 & 0.09 & NS & NS & NS \\
\hline $\operatorname{Motility}^{4}(\%)$ & 71.7 & 63.1 & 13.8 & 25.1 & 11.0 & NS & $<0.01$ & NS \\
\hline Volume, ${ }^{4} 3 \mathrm{~h}\left(\log _{10} \mu \mathrm{m}\right)$ & 3.62 & 3.68 & 3.64 & 3.54 & 0.68 & NS & NS & NS \\
\hline
\end{tabular}

${ }^{1}$ Treatments containing monensin at $2.82 \mu M$ or CinnaGar at $0.0043 \%$ on a DM basis.

${ }^{2}$ Rumensin was provided by Elanco Animal Health (Greenfield, IN); CinnaGar was provided by Provimi North America Inc. (Brookville, OH).

${ }^{3}$ Main effects or interaction of monensin (MON) and CinnaGar (CIN); NS: $P>0.15$.

${ }^{4}$ Hour 0 was used as a covariate for motile $\%$ estimations at $6 \mathrm{~h}$ after incubation in treatments. 
total $\mathrm{N}$ flows (NAN plus $\mathrm{NH}_{3} \mathrm{~N}$ ) were lower than $\mathrm{N}$ intake, probably caused by experimental error, removal of fermentor samples that were taken during sampling days (decreased the recovery of total $\mathrm{N}$ in effluent), and feed and microbes collecting on the filters. The MON increased the peptide- $\mathrm{N}$ concentration. Unlike ruminally derived samples from which these small particles can generally be removed by flocculation (removal of floating particles), protozoa repeatedly co-filtered with small particles from the effluent samples, resulting in overestimation of protozoal N per cell (Sylvester et al., 2009), as also shown in our results with higher protozoal $\mathrm{N}$ per cell calculated only with NBS retentates than the one calculated with the by-difference procedure (Figure 1). We used protozoal $\mathrm{N}$ per cell calculated from the by-difference procedure for the other effluent $\mathrm{N}$ flow calculations. Boiling-water bath and sonication for a certain time period disrupted $100 \%$ of the protozoa (Coleman, 1992), which was consistent with our pre- liminary test where we found about $95 \%$ of protozoa were disrupted after boiling for $5 \mathrm{~min}$ and sonicated for 2 min (data not shown).

Evaluating the ${ }^{15} \mathrm{~N}$ enrichment ratios of protozoa relative to bacteria (ranging from 0.536 to 0.576 ) suggested that not correcting protozoa for feed $\mathrm{N}$ contamination underestimated this ratio compared with estimates that protozoa incorporate most of their protein from bacteria (i.e., a ratio closer to 0.7 or above being expected; Williams and Coleman, 1992). Our correction procedure yielded a higher ratio $(\geq 0.835)$ that is more consistent with expectations. However, this ratio was more variable and resulted in an impossible value of over 1.0 for the treatment containing both MON and CIN, which was within the confidence interval for 1.0 as verified by the large SEM. The mean $\mathrm{N}$ per cell with the by-difference procedure ranged from 3.05 to $9.80 \mathrm{ng}$, whereas the calculation only with $\mathrm{N}$ in NBS retentates ranged from 16.1 to $28.2 \mathrm{ng}$. Sylvester et

Table 5. The NDF and OM digestibilities, $\mathrm{N}$ fractions, and bacterial efficiency in continuous cultures fed diets without $(-)$ or with $(+)$ monensin and CinnaGar in experiment $1^{1}$

\begin{tabular}{|c|c|c|c|c|c|c|c|c|}
\hline Item & \multicolumn{4}{|c|}{ Monensin/CinnaGar ${ }^{2}$} & SEM & \multicolumn{3}{|c|}{$P$-value ${ }^{3}$} \\
\hline Apparent OM digestibility (\%) & 48.0 & 47.8 & 48.5 & 46.5 & 1.6 & NS & NS & NS \\
\hline NDF digestibility (\%) & 58.8 & 57.1 & 58.2 & 52.8 & 12.0 & 0.11 & NS & NS \\
\hline $\mathrm{NH}_{3} \mathrm{~N}(\mathrm{mg} / \mathrm{dL})$ & 15.0 & 14.9 & 15.0 & 15.6 & 0.4 & NS & NS & NS \\
\hline Peptide $\mathrm{N}^{4}(\mathrm{mg} / \mathrm{dL})$ & 7.47 & 7.85 & 8.41 & 8.44 & 0.41 & NS & 0.05 & NS \\
\hline \multicolumn{9}{|l|}{ Effluent $\mathrm{N}$ flow } \\
\hline Microbial N (g/d) & 0.504 & 0.369 & 0.478 & 0.334 & 0.049 & 0.07 & NS & NS \\
\hline Protozoal N (g/d) & 0.250 & 0.119 & 0.254 & 0.071 & 0.049 & 0.05 & NS & NS \\
\hline Bacterial N (g/d) & 0.259 & 0.251 & 0.226 & 0.263 & 0.013 & NS & NS & 0.15 \\
\hline $\operatorname{NAN}^{8}(\mathrm{~g} / \mathrm{d})$ & 0.861 & 0.871 & 0.815 & 0.862 & 0.032 & NS & NS & NS \\
\hline $\mathrm{NAN}^{9}(\%$ of $\mathrm{N}$ intake) & 86.0 & 87.5 & 82.1 & 86.4 & 3.2 & NS & NS & NS \\
\hline $\operatorname{NANMN}^{10}(\mathrm{~g} / \mathrm{d})$ & 0.357 & 0.503 & 0.337 & 0.528 & 0.052 & 0.05 & NS & NS \\
\hline
\end{tabular}

${ }^{1}$ Diets contained monensin at $11 \mathrm{~g} / 909 \mathrm{~kg}$ or CinnaGar at $0.0043 \%$ on a DM basis.

${ }^{2}$ Rumensin was provided by Elanco Animal Health (Greenfield, IN); CinnaGar was provided by Provimi North America Inc. (Brookville, OH).

${ }^{3}$ Main effects or interaction of monensin (MON) and CinnaGar (CIN). NS: $P>0.15$.

${ }^{4}$ Peptide $\mathrm{N}=$ trichloroacetic acid-soluble $\mathrm{N}$ minus $\mathrm{NH}_{3} \mathrm{~N}$.

${ }^{5}$ Protozoa $\mathrm{N}$ was calculated only with $\mathrm{N}$ in not boiled or sonicated (NBS) retentates (Figure 1).

${ }^{6}$ Protozoa $\mathrm{N}$ was calculated as $\mathrm{N}$ from NBS minus $\mathrm{N}$ from boiled and sonicated retentates (Figure 1). All the other effluent flow calculations used this protozoa $\mathrm{N}$.

${ }^{7}$ The control and MON treatments had missing values in period 1. The SEM is approximately $20 \%$ lower than the repeated SEM.

${ }^{8} \mathrm{NAN}=$ total $\mathrm{N}$ flow minus $\mathrm{NH}_{3} \mathrm{~N}$.

${ }^{9} \mathrm{~N}$ intake was from feed and did not include $\mathrm{N}$ addition from buffer.

${ }^{10} \mathrm{NANMN}=$ nonammonia-nonmicrobial $\mathrm{N}=\mathrm{NAN}$ minus microbial $\mathrm{N}$.

${ }^{11} \mathrm{~N}$ efficiency $=$ grams microbial $\mathrm{N}$ produced/kilogram OM truly degraded.

${ }^{12}$ Calculated only with protozoa ${ }^{15} \mathrm{~N}$ from NBS retentates.

${ }^{13}$ Calculated by difference of protozoa ${ }^{15} \mathrm{~N}$ from NBS and boiled and sonicated retentates. 
al. (2004) reported $\mathrm{N}$ per cell at $0.546 \mathrm{ng}$, and using purified substrates (to avoid contamination by $\mathrm{N}$ in feeds), our approach yielded values of around 1.1 to 1.3 ng/cell (Table 4; experiment 2). Boiling and sonication also could disrupt bacterial cells, but we presume our protozoal samples had only minor contamination with bacteria based on our previous work (Sylvester et al., 2005). Therefore, the boiling and sonication approach used for the data in Table 5 provides more reasonable values than the standard approach; discrepancies could be a result of larger cell size in experiment 1 (continuous culture) than experiment 2 (batch culture). Standardization of cell size with videography would help explain these results.

The CIN tended $(P=0.07)$ to decrease microbial N flow as a result of decreased protozoal $\mathrm{N}$ flow (Table 5). The decreased protozoal $\mathrm{N}$ is at least in part a result of the decreased $\mathrm{N} /$ cell for this treatment, which might be in part an artifact of aldehydes protecting $\mathrm{N}$ from disruption by boiling and sonication. The decrease in protozoal $\mathrm{N}$ flow by CIN, without a corresponding increase in bacterial $\mathrm{N}$ flow, would be inconsistent with expectations of increased bacterial $\mathrm{N}$ to compensate for the void from reduced protozoa (Firkins et al., 2007), although an alternative explanation is that protozoa still acquired substrate but did not convert it efficiently into protozoal biomass because they were using those nutrients to counteract the inhibition. Berger (2001) reported that the environmental ciliate, Paramecium, responded to nutrient stress by decreasing the percentage of cells that are in a division state or increasing those that undergo autophagy. Thus, protozoa could still be acquiring substrate, but CIN could be uncoupling their ability to convert it into cellular constituents, explaining why decreased protozoal $\mathrm{N}$ did not increase bacterial $\mathrm{N}$.

The flow of bacterial $\mathrm{N}$ tended $(P=0.15)$ to be increased as a nonadditive response to the interaction of MON and CIN. The CIN increased NANMN when calculated as both flow and the percentage of $\mathrm{N}$ intake. The MON decreased bacteria ${ }^{15} \mathrm{~N}_{\mathrm{N}} \mathrm{NH}_{3}{ }^{15} \mathrm{~N}$ ratio, but CIN increased it. The CIN tended to decrease $\mathrm{N}$ per cell $(P=0.09)$, which is most likely caused by the decrease in cell counts $(P=0.07$; Table 4$)$ rather than a change in cell volume (experiment 2 ). In the by-difference procedure for cell volume in experiment 1 , the effect of boiling and sonication may have caused soluble proteins bound by aldehydes in the CIN treatment to retain in the protozoal fraction, hence contributing to the trend of decreased $\mathrm{N}$ per cell. The MON tended ( $P$ $=0.09)$ to decrease the cell volume. With the absence of an effect by CIN and the trend induced by MON, time might have been too short in vitro to see a change. Teather et al. (1984) used the empirical formula for mixed protozoal populations, whereas Dehority (2010) used the cylinder function on Epidinium caudatum. As videography enables the ellipsoid method to estimate 3-dimensional protozoal volume (Wenner et al., 2018), further research is needed on the effect of inhibitors on protozoal cell volume in longer incubations to back up the by-difference procedures to measure N:cell (removing contaminating feed $\mathrm{N}$ ) when used with outflows of cells per day to compute protozoal N.

The CIN increased nonammonia nonmicrobial $\mathrm{N}$ (NANMN; an estimate of undegraded protein). There was a trend $(P=0.07)$ for CIN to decrease protozoa counts (Table 3), which explained the increased NANMN flow (decreased proteolysis) because a decrease in protozoal populations would be expected to decrease protease activity (Williams and Coleman, 1992; Walker et al., 2005). Although MON increased peptides, apparently as a result of inhibited hyperammonia-producing bacteria, these bacteria do not contribute much to proteolysis and therefore did not affect NANMN. Although not consistent, these responses are supported by some studies (Cobellis et al., 2016). One explanation for the increased NANMN by CIN is the nature of the dualflow fermentor system. The preprocessing by grinding and stirring for the diets provides more small particles to pass with the overflow compared with in vivo or in vitro (Karnati et al., 2009).

\section{VFA}

No interaction was observed of MON and CIN for the production of total VFA or any individual VFA (Table 6$)$. A trend $(P=0.15)$ was observed for CIN to increase the production of isovalerate; however, neither MON nor CIN affected the production of total VFA, acetate, isobutyrate, butyrate, or valerate. The MON tended $(P=0.10)$ to increase propionate production, and it increased isovalerate production and decreased acetate:propionate ratio from 4.6 to 3.8 . The latter is expected based on previous research (Ipharraguerre and Clark, 2003). Also, Fellner et al. (1997) noted that MON added at $2 \mu \mathrm{g} / \mathrm{mL}(2.89 \mu M)$ of fermentor fluid decreased acetate:propionate ratio from 3.0 to 1.7. Jenkins et al. (2003) reported that feeding MON (25 $\mathrm{ppm})$ to fermentors with a diet of 30:70 alfalfa hay: concentrate decreased acetate:propionate ratio and increased molar proportions of acetate, propionate, and butyrate. However, MON fed at $12 \mathrm{~g} / 909 \mathrm{~kg}$ of DM to lactating Holstein cows did not show a decrease in acetate:propionate ratio (Mathew et al., 2011), and this response is not consistent, perhaps because its mode of action is probably much more diverse than the generalized expectation against gram-positive bacteria (Scharen et al., 2017). 
Supplementing cinnamaldehyde $(0.6 \mathrm{~g} / \mathrm{d})$ and eugenol $(0.3 \mathrm{~g} / \mathrm{d})$ to Holstein heifers decreased the branched-chain VFA, such as isobutyrate and isovalerate (Cardozo et al., 2006). Patra and Yu (2012) reported decreased molar percentage of valerate by garlic oil added at $1 \mathrm{~g} / \mathrm{L}$ in vitro, but isovalerate was not affected at $0.25,0.5$, or $1 \mathrm{~g} / \mathrm{L}$. Besides the unconfirmed mode of action for cinnamaldehyde, as the main active component of cinnamon bark oil, it may interact with other dietary components; thus, its structure and concentration might be the cause of inconsistent results (Macheboeuf et al., 2008). For both MON and CIN, the responses may be affected by composition and physical characteristics of diets.

\section{Methane Production}

The interaction of MON and CIN tended $(P=0.06)$ to increase methane production (Table 6 ), which was contrary to our hypothesis. The dose of EO in our study was lower than most of those in batch culture studies reviewed by Benchaar and Greathead (2011), but comparing between continuous and batch cultures is problematic. Cinnamon oil and garlic oil added at $>300 \mathrm{mg} / \mathrm{L}$ were effective at decreasing methane production in vitro. However, methane emission was not affected by adding cinnamon oil (50 mg/ $\mathrm{kg}$ of DMI), cinnamaldehyde $(50 \mathrm{mg} / \mathrm{kg}$ of DMI), or MON (24 mg/ $\mathrm{kg}$ of DMI) to lactating cows (Benchaar, 2016). The numerically lower methane production with MON is stoichiometrically consistent with increased propionate. The MON can decrease methanogenesis (Odongo et al., 2007), but this has not been consistently observed (Beauchemin et al., 2008). Perhaps, the slowing of growth rate by MON (longer generation time, Table 3), combined with uncoupling of cellular energy by CIN through impaired membrane permeability, might have caused compensatory uptake and fermentation by protozoa to try to overcome the combined treatment. Wenner et al. (2018) noted an interaction for MON and CIN at $3 \mathrm{~h}$ on protozoal motility, such that CIN appeared to minimize the negative effects of MON on protozoal motility. Particularly during the first few hours after feeding (Firkins and Yu, 2006; Ushida, 2010), when protozoal activity would be expected to be greatest, the combined effects of these compounds could have promoted excessive protozoal $\mathrm{H}_{2}$ production during fermentation in an effort to compensate for uncoupled ATP synthesis.

Methane production can be uncoupled from methanogen abundance (Mosoni et al., 2011) and is not necessarily correlated with protozoal counts (Morgavi et al., 2012). Thus, inhibition strategies probably reduce cellular metabolic capacity of protozoa (not necessarily cell counts). Further work is needed regarding how to inhibit protozoa enough to decrease their negative effects but not so much as to disrupt normal microbial ecology of the rumen.

\section{Effluent Flow and Biohydrogenation of FA}

The MON tended $(P=0.07)$ to decrease the flow of 18:0 and increased $(P=0.02)$ the flow of $18: 1$ trans -11 (Table 7). As a result, 18:1 trans-11:trans-10 and 18:1 trans-11:total 18:0 ratios increased and the biohydrogenation extent of total C18 FA decreased, particularly the 18:1 cis- 9 biohydrogenation. Thus, MON disrupted the complete biohydrogenation of unsaturated FA (increased 18:1 trans-11) in a manner considered favorable for milk fat synthesis (Jenkins et al., 2008). Although high amounts of free oil and nonstructural carbohydrate are primary risk factors for formation of trans-10 FA, MON has been advocated to possibly promote the formation of such FA, but this has not always been

Table 6. Fermentation characteristics in continuous cultures fed diets without $(-)$ or with $(+)$ monensin and CinnaGar in experiment $1^{1}$

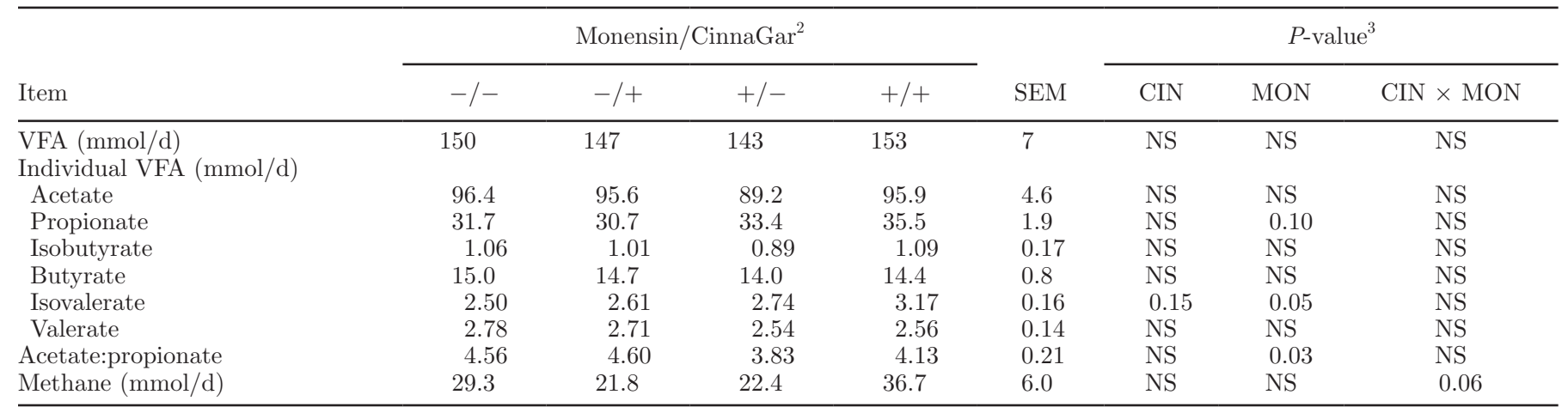

${ }^{1}$ Diets contained monensin at $11 \mathrm{~g} / 909 \mathrm{~kg}$ or CinnaGar at $0.0043 \%$ on a DM basis.

${ }^{2}$ Rumensin was provided by Elanco Animal Health (Greenfield, IN); CinnaGar was provided by Provimi North America Inc. (Brookville, OH).

${ }^{3}$ Main effects or interaction of monensin (MON) and CinnaGar (CIN). NS: $P>0.15$. 
Table 7. Flow and biohydrogenation of long-chain fatty acids (FA) in effluent from continuous cultures fed diets without $(-)$ or with $(+)$ monensin and CinnaGar in experiment $1^{1}$

\begin{tabular}{|c|c|c|c|c|c|c|c|c|}
\hline \multirow[b]{2}{*}{ Item } & \multicolumn{4}{|c|}{ Monensin/CinnaGar ${ }^{2}$} & \multirow[b]{2}{*}{ SEM } & \multicolumn{3}{|c|}{$P$-value ${ }^{3}$} \\
\hline & $-/-$ & $-/+$ & $+/-$ & $+/+$ & & CIN & $\mathrm{MON}$ & $\mathrm{CIN} \times \mathrm{MON}$ \\
\hline \multicolumn{9}{|l|}{ Flow $(\mathrm{mg} / \mathrm{d})$} \\
\hline $18: 0$ & 325 & 321 & 267 & 277 & 30 & NS & 0.07 & NS \\
\hline $18: 1$ cis-9 & 110 & 102 & 116 & 110 & 2 & NS & NS & NS \\
\hline $18: 1$ trans -10 & 13.1 & 13.5 & 13.8 & 15.2 & 1.5 & NS & NS & NS \\
\hline 18:1 trans-11 & 185 & 181 & 224 & 223 & 15 & NS & 0.02 & NS \\
\hline $18: 3 n-3$ & 55.6 & 41.5 & 56.5 & 47.2 & 8.7 & NS & NS & NS \\
\hline Total C18 & 876 & 836 & 873 & 853 & 64 & NS & NS & NS \\
\hline \multicolumn{9}{|l|}{ Biohydrogenation $^{5}$} \\
\hline Total C18 & 51.0 & 52.8 & 45.6 & 48.6 & 2.4 & 0.10 & 0.01 & NS \\
\hline $18: 1$ cis-9 & 42.4 & 43.6 & 38.7 & 41.0 & 0.7 & 0.03 & $<0.01$ & NS \\
\hline $18: 2$ & 67.5 & 68.9 & 65.1 & 67.6 & 2.6 & 0.14 & NS & NS \\
\hline $18: 3$ & 67.5 & 71.6 & 63.9 & 69.1 & 3.3 & 0.13 & NS & NS \\
\hline
\end{tabular}

${ }^{1}$ Diets contained monensin at $11 \mathrm{~g} / 909 \mathrm{~kg}$ or CinnaGar at $0.0043 \%$ on a DM basis.

${ }^{2}$ Rumensin was provided by Elanco Animal Health (Greenfield, IN); CinnaGar was provided by Provimi North America Inc. (Brookville, OH).

${ }^{3}$ Main effects or interaction of monensin (MON) and CinnaGar (CIN). NS: $P>0.15$.

${ }^{4}$ Geometrical and positional isomers of CLA.

${ }^{5}$ Calculated as percentage of C18 FA that disappeared between intake and effluent flow (Tice et al., 1994); total C18 FA were weighted for the number of unsaturated bonds.

${ }^{6} \mathrm{VA}=\operatorname{vaccenic}$ acid $(18: 1$ trans-11); UFA $=$ total C18 UFA; trans-10 = 18:1 trans-10.

observed in other studies (Mathew et al., 2011). Interactions among protozoa and bacteria for effects on biohydrogenation remain elusive (Firkins et al., 2008; Jenkins et al., 2008).

The CIN did not affect FA flow under the conditions of our study, but it increased the biohydrogenation extent of 18:1 cis- 9 . It tended to increase the biohydrogenation of total $\mathrm{C} 18(P=0.10), 18: 2(P=$ $0.14)$, and 18:3 $(P=0.13)$, which indicated a possible increase of bacterial population to hydrogenate the FA. Yet, CIN tended $(P=0.07)$ to decrease the total protozoal counts (Table 3) and numerically increased the generation time of protozoa, which do not directly carry out biohydrogenation (Dawson and Kemp, 1969).

In summary, no effects were detected of CIN or MON on protozoal populations, concentration of $\mathrm{NH}_{3} \mathrm{~N}$, total $\mathrm{N}$ flow of effluent, production of total VFA, or flows of CLA and total C18 FA. The MON decreased acetate: propionate ratio and biohydrogenation of both total C18 and 18:1 cis-9 but increased protozoal generation time, concentration of peptides, and flow of 18:1 trans-11. The CIN decreased true OM digestibility and protozoal $\mathrm{N}$ flow of effluent but increased NANMN flow. The MON decreased percentage of protozoa that were motile; however, CIN did not affect protozoal cell count, motility, or volume. Under the conditions of our study, we did not detect an additive response for
MON and CIN to decrease protozoal counts or methane production, as hypothesized. A 3-dimensional method for determining protozoal volume was presented that is thought to improve estimation of protozoal volume used in ruminant nutrition studies.

\section{ACKNOWLEDGMENTS}

Our thanks are extended to Provimi North America (Brookville, $\mathrm{OH}$ ) and Elanco Animal Health (Greenfield, IN) for funding this project. We are grateful to Donna Wyatt at the Wooster campus of The Ohio State University for the VFA analysis, Alex Hristov for ${ }^{15} \mathrm{~N}$ analysis in the Stable Isotope Laboratory at Pennsylvania State University (University Park), Normand StPierre (professor emeritus, The Ohio State University, Columbus) for statistical help, and all the students and laboratory technicians who helped with this project.

\section{REFERENCES}

AlZahal, O., N. E. Odongo, T. Mutsvangwa, M. M. Or-Rashid, T. F. Duffield, R. Bagg, P. Dick, G. Vessie, and B. W. McBride. 2008. Effects of monensin and dietary soybean oil on milk fat percentage and milk fatty acid profile in lactating dairy cows. J. Dairy Sci. 91:1166-1174.

AOAC International. 1990. Official Methods of Analysis. 15th ed. AOAC International, Arlington, VA. 
Beauchemin, K. A., M. Kreuzer, F. O. O'Mara, and T. A. McAllister. 2008. Nutritional management for enteric methane abatement: A review. Aust. J. Exp. Agric. 48:21-27.

Benchaar, C. 2016. Diet supplementation with cinnamon oil, cinnamaldehyde, or monensin does not reduce enteric methane production of dairy cows. Animal 10:418-425.

Benchaar, C., and P. Y. Chouinard. 2009. Short communication: Assessment of the potential of cinnamaldehyde, condensed tannins, and saponins to modify milk fatty acid composition of dairy cows. J. Dairy Sci. 92:3392-3396.

Benchaar, C., and H. Greathead. 2011. Essential oils and opportunities tomitigate enteric methane emissions from ruminants. Anim. Feed Sci. Technol. 166:338-355.

Benchaar, C., T. A. McAllister, and P. Y. Chouinard. 2008. Digestion, ruminal fermentation, ciliate protozoal populations, and milk production from dairy cows fed cinnamaldehyde, quebracho condensed tannin, or yucca schidigera saponin extracts. J. Dairy Sci. 91:4765-4777.

Bergen, W. G., and D. B. Bates. 1984. Ionophores: Their effect on production efficiency and mode of action. J. Anim. Sci. 58:1465-1483.

Berger, J. D. 2001. Riding the ciliate cell cycle-A thirty-five-year prospective. J. Eukaryot. Microbiol. 48:505-518.

Busquet, M., S. Calsamiglia, A. Ferret, M. D. Carro, and C. Kamel. 2005. Effect of garlic oil and four of its compounds on rumen microbial fermentation. J. Dairy Sci. 88:4393-4404.

Calsamiglia, S., M. Busquet, P. W. Cordozo, L. Castillejos, and A. Ferret. 2007. Invited Review: Essential oils as modifiers of rumen microbial fermentation. J. Dairy Sci. 90:2580-2595.

Cardozo, P. W., S. Calsamiglia, A. Ferret, and C. Kamel. 2006. Effects of alfalfa extract, anise, capsicum and a mixture of cinnamaldehyde and eugenol on rumenial fermentation and protein degradation in beef heifers fed a high concentrate diet. J. Anim. Sci. 84:2801-2808.

Chen, M., and M. J. Wolin. 1979. Effect of monensin and lasalocidsodium on the growth of methanogenic and rumen saccharolytic bacteria. Appl. Environ. Microbiol. 38:72-77.

Cobellis, G., M. Trabalza-Marinucci, and Z. Yu. 2016. Critical evaluation of essential oils as rumen modifiers in ruminant nutrition: A review. Sci. Total Environ. 545-546:556-568.

Coleman, G. S. 1992. The rate of uptake and metabolism of starch grains and cellulolse particles by Entodinium species, Eudiplodinium magii, and some other entodiniomorphid protozoa and natural protozoal populations taken from the ovine rumen. J. Appl. Bacteriol. 73:507-513.

Dawson, R. M. C., and P. Kemp. 1969. The effect of defaunation on the phospholipids and on the hydrogenation of unsaturated fatty acids in the rumen. Biochem. J. 115:351-352.

Dehority, B. A. 1993. Laboratory manual for classification and morphology of rumen ciliate protozoa. CRC Press, Boca Raton, FL.

Dehority, B. A. 2010. Physiological characteristics of several rumen protozoa grown in vitro with observations on within and among species variation. Eur. J. Protistol. 46:271-279.

Diaz, H. L., K. N. Barr, K. R. Godden, J. E. Plank, I. Zapata, A. N. Schappacher, M. P. Wick, and J. L. Firkins. 2014. Eukaryotic inhibitors or activators elicit responses to chemosensory compounds by ruminal isotrichid and entodiniomorphid protozoa. J. Dairy Sci. $97: 2254-2269$

Fellner, V., F. D. Sauer, and J. K. G. Kramer. 1997. Effect of nigericin, monensin, and tetronasin on biohydrogenation in continuous flowthrough ruminal fermenters. J. Dairy Sci. 80:921-928.

Firkins, J. L., S. K. R. Karnati, and Z. Yu. 2008. Linking rumen function to animal response by application of metagenomics techniques. Aust. J. Exp. Agric. 48:711-721.

Firkins, J. L., W. P. Weiss, M. L. Eastridge, and B. L. Hull. 1990. Effects of feeding fungal culture extract and animal-vegetable fat on degradation of hemicellulose and on bacterial growth in heifers. J. Dairy Sci. 73:1812-1822.

Firkins, J. L., and Z. Yu. 2006. Characterization and quantification of the microbial populations in the rumen. Pages 19-54 in Ruminant Physiology, Digestion, Metabolism and Impact of Nutrition on Gene Expression, Immunology and Stress. K. Sejrsen, T. Hvel- plund, and M. O. Nielsen, eds. Wageningen Academic Publishers, Wageningen, the Netherlands.

Firkins, J. L., Z. Yu, and M. Morrison. 2007. Ruminal nitrogen metabolism: Perspectives for integration of microbiology and nutrition for dairy. J. Dairy Sci. 90(E. Suppl.):E1-E16.

Gill, A. O., and R. A. Holley. 2004. Mechanisms of bactericidal action of cinnamaldehyde against Listeria monocytogenes and of eugenol against L. monocytogenes and Lactobacillus sakei. Appl. Environ. Microbiol. 70:5750-5755.

Hackmann, T. J., L. E. Diese, and J. L. Firkins. 2013. Quantifying the responses of mixed rumen microbes to excess carbohydrate. Appl Environ. Microbiol. 79:3786-3795.

Hart, K. J., D. R. Yáñez-Ruiz, S. M. Duval, N. R. McEwan, and C. J Newbold. 2008. Plant extracts to manipulate rumen fermentation. Anim. Feed Sci. Technol. 147:8-35.

Hoover, W. H., B. A. Crooker, and C. J. Sniffen. 1976. Effects of differential solid-liquid removal rates on protozoa numbers in continuous cultures of rumen contents. J. Anim. Sci. 43:528-534.

Hristov, A. N., P. Huhtanen, L. M. Rode, S. N. Acharya, and T. A. McAllister. 2001. Comparison of the ruminal metabolism of nitrogen from ${ }^{15} \mathrm{~N}$-labeled alfalfa preserved as hay or as silage. J. Dairy Sci. 84:2738-2750.

Ipharraguerre, I. R., and J. H. Clark. 2003. Usefulness of ionophores for lactating dairy cows: A review. Anim. Feed Sci. Technol. 106:39-57.

Jenkins, T. C., V. Fellner, and R. K. McGuffey. 2003. Monensin by fat interactions on trans fatty acids in cultures of mixed ruminal microorganisms grown in continuous fermenters fed corn or barley. J. Dairy Sci. 86:324-330.

Jenkins, T. C., R. J. Wallace, P. J. Moate, and E. E. Mosley. 2008. Board-Invited Review: Recent advances in biohydrogenation of unsaturated fatty acids within the rumen microbial ecosystem. J. Anim. Sci. 86:397-412.

Karnati, S. K. R., J. T. Sylvester, C. V. D. M. Ribeiro, L. E. Gilligan, and J. L. Firkins. 2009. Investigating unsaturated fat, monensin or bromoethanesulfonate in continuous cultures retaining ruminal protozoa. I. Fermentation, biohydrogenation, and microbial protein synthesis. J. Dairy Sci. 92:3849-3860.

Lourenço, M., P. W. Cardozo, S. Calsamiglia, and V. Fievez. 2008. Effects of saponins, quercetin, eugenol, and cinnamaldehyde on fatty acid biohydrogenation of forage polyunsaturated fatty acids in dual-flow continuous culture fermenters. J. Anim. Sci. 86:3045-3053.

Macheboeuf, D., D. P. Morgavi, Y. Papon, J. L. Mousset, and M. Arturo-Schaan. 2008. Dose-response effects of essential oils on in vitro fermentation activity of the rumen microbial population. Anim. Feed Sci. Technol. 145:335-350.

Mathew, B., M. L. Eastridge, E. R. Oelker, J. L. Firkins, and S. K R. Karnati. 2011. Interactions of monensin with dietary fat and carbohydrte components on ruminal fermentation and production responses by dairy cows. J. Dairy Sci. 94:396-409.

Morgavi, D. P., C. Martin, J.-P. Jouany, and M. J. Ranilla. 2012. Rumen protozoa and methanogenesis: Not a simple cause-effect relationship. Br. J. Nutr. 107:388-397.

Mosoni, P., C. Martin, E. Forano, and D. P. Morgavi. 2011. Long-term defaunation increases the abundance of cellulolytic ruminococci and methanogens but does not affect the bacterial and methanogen diversity in the rumen of sheep. J. Anim. Sci. 89:783-791.

Newbold, C. J., G. de la Fuente, A. Belanche, E. Ramos-Morales, and N. R. McEwan. 2015. The role of ciliate protozoa in the rumen. Front. Microbiol. 6:1313.

Noftsger, S. M., N. R. St-Pierre, S. K. R. Karnati, and J. L. Firkins. 2003. Effects of 2-hydroxy-4-(methylthio) butanoic acid (HMB) on microbial growth in continuous culture. J. Dairy Sci. 86:2629-2636.

Odongo, N. E., R. Bagg, G. Vessie, P. Dick, M. M. Or-Rashid, S. E. Hook, J. T. Gray, E. Kebreab, J. France, and B. W. McBride. 2007. Long-term effects of feeding monensin on methane production in lactating dairy cows. J. Dairy Sci. 90:1781-1788.

Patra, A. K., and Z. Yu. 2012. Effects of essential oils on methane production and fermentation by, and abundance and diversity of, rumen microbial populations. Appl. Environ. Microbiol. 78:42714280 
Russell, J. B., and H. J. Strobel. 1989. Effect of ionophores on ruminal fermentation. Appl. Environ. Microbiol. 55:1-6.

Scharen, M., C. Drong, K. Kiri, S. Riede, M. Gardener, U. Meye, J. Hummel, T. Urich, G. Breves, and S. Danicke. 2017. Differential effects of monensin and a blend of essential oils on rumen microbiota composition of transition dairy cows. J. Dairy Sci. 100:2765-2783.

Schneider, C. A., W. S. Rasband, and K. W. Eliceiri. 2012. NIH Image to ImageJ: 25 years of image analysis. Nat. Methods 9:671-675.

Sylvester, J. T., S. K. R. Karnati, B. A. Dehority, M. Morrison, G. L. Smith, N. R. St-Pierre, and J. L. Firkins. 2009. Rumen protozoa decrease generation time and adjust $18 \mathrm{~S}$ ribosomal DNA copies to adapt to decreased transfer interval, starvation, and monensin. J. Dairy Sci. 92:256-269.

Sylvester, J. T., S. K. R. Karnati, Z. Yu, M. Morrison, and J. L. Firkins. 2004. Development of an assay to quantify rumen ciliate protozoal biomass in cows using real-time PCR. J. Nutr. 134:3378 3384 .

Sylvester, J. T., S. K. R. Karnati, Z. Yu, C. J. Newbold, and J. L. Firkins. 2005. Evaluation of a real-time PCR assay for measuring the ruminal pool and duodenal flow of protozoal nitrogen. J. Dairy Sci. 88:2083-2095.

Teather, R. M., S. Mahadevan, J. D. Erfle, and F. D. Sauer. 1984 Negative correlation between protozoal and bacterial levels in rumen samples and its relation to the determination of dietary effects on the rumen microbial population. Appl. Environ. Microbiol. 47:566-570.
Tedeschi, L., D. Fox, and T. Tylutki. 2003. Potential environmental benefits of ionophores in ruminant diets. J. Environ. Qual. 32:1591-1602.

Tice, E. M., M. L. Eastridge, and J. L. Firkins. 1994. Raw soybeans and roasted soybeans of different particle sizes. 2. Fatty acid utilization by lactating cows. J. Dairy Sci. 77:166-180.

Ushida, K. 2010. Symbiotic methanogens and rumen ciliates. Pages 25-34 in (Endo)symbiotic Methanogenic Archaea. J. H. P. Hackstein, ed. Springer-Verlag, Heidelberg, Germany.

Van Soest, P. J., J. B. Robertson, and B. A. Lewis. 1991. Methods for dietary fiber, neutral detergent fiber, and nonstarch polysaccharides in relation to animal nutrition. J. Dairy Sci. 74:3583-3597.

Walker, N. D., C. J. Newbold, and R. J. Wallace. 2005. Nitrogen metabolism in the rumen. Pages 71-115 in Nitrogen and Phosphorus Nutrition of Cattle. E. Pfeffer and A. Hristov, ed. CABI Publishing, Cambridge, MA

Wenner, B. A., B. K. Wagner, and J. L. Firkins. 2018. Using video microscopy to improve quantitative estimates of protozoal motility and cell volume. J. Dairy Sci. 101:1060-1073.

Williams, A. G. and G. S. Coleman. 1992. The Rumen Protozoa. Springer-Verlag, New York, NY.

Williams, Y. J., S. Popovski, S. M. Rea, L. C. Skillman, A. F. Toovey, K. S. Northwood, and A.-D. G. Wright. 2009. A vaccine against rumen methanogens can alter the composition of archaeal populations. Appl. Environ. Microbiol. 75:1860-1866. 